\title{
LUCIO FLÁVIO, O PASSAGEIRO DA AGONIA, de Hector Babenco
}

Cinema: the representation of journalist in Lúcio Flávio, o passageiro da agonia

Lisandro Nogueira

Prof. Dr. do Curso de Comunicação da UFG

E-mail: lisandro@cultura.com.br.

Resumo:

A representação do jornalista nos filmes brasileiros dos anos 60 difere dos newpapers movies americanos da época. Nos filmes Boca de Ouro (62), O desafio(65) e Terra em Transe (67) o jornalista não é herói e nem vilão, descartando-se o melodrama como estratégia narrativa. A partir dos anos 70 , esse olhar crítico se esvai e ganha corpo o filme de jornalista atrelado ao modelo americano. Lúcio Flávio, o passageiro da agonia é exemplo de uma nova maneira de representar o jornalista no cinema brasileiro.

Palavras-chave: cinema e jornalismo, filmes de jornalista, jornalista, filme brasileiro.

O filme de Hector Babenco, Lúcio Flávio, o passageiro da agonia (1976), é simbólico ao retratar o crepúsculo de uma representação do jornalista ancorada no contexto dos anos 60 . Há uma mudança no contexto, a partir dos anos 70 , que desloca a relação dos cineastas com o "diagnóstico da naçāo", preceito básico que os orientava na compreensão do processo político do Brasil. O jornalista foi personagem fundamental para $o$ diagnóstico, pois simbolizava as contradiçóes, as ambigüidades $\mathrm{e}$ as desilusôes.

A representação do jornalista nos filmes brasileiros dos anos 60 destoava dos newspapers movies americanos, complacentes com o melodrama e vinculados à idéia maniqueísta do bem contra o mal (o herói e o vilāo). O personagem jornalista ecoava sentimentos e atitudes presentes na vida social. Era desvinculado de uma representação superficial, como na maioria dos filmes americanos sobre jornalistas, mas atado a um projeto de construçāo estética e crítica política. Além do projeto de intervenção, alguns criticavam e faziam também um diagnóstico por dentro da profissão e seus conceitos.

Boca de ouro (1962) faz uma ironia incisiva sobre a objetividade jornalística; $O$ Desafio (1965) mostra a "inércia perplexa" do jornalista-intelectual, usando falas redundantes e imagens primorosas para chegar ao cinismo absoluto do repórter- fotográfico de Brasil Ano 2000
(1969). Nelson Pereira, com o suporte de Nelson Rodrigues, perpetra uma crítica ao jornalismo e atravessa um olhar duro sobre a nascente indústria cultural. As misturas entre o intelectual e o jornalista povoam o filme de Saraceni e abrem o abismo para a definitiva palavra de Paulo Martins, em Terra em Transe (Glauber Rocha), sobre as possibilidades de intervenção desse profissional/intelectual na vida do Brasil. O pessimismo delirante de Martins ecoa de forma melancólica nas décadas seguintes, em filmes como Lúcio Flávio, o passageiro da agonia (1977), $O$ beijo no asfalto (1981) e Doces Poderes (1996).

O jornalista do filme de Hector Babenco é atrelado às vontades do regime militar; o jornalista do filme de Bruno Barreto é um escroque, em conluio com a polícia civil. A jornalista de Doces Poderes é rendida numa guerra em que a publicidade e o marketing vencem o jornalismo.

Os dois primeiros filmes săo passagens para se chegar aos anos 90 , quando se confirma outra configuração para o jornalista. Lúcio Flávio vai exibir um jornalista sem força de intervenção, ou sequer de reflexão. No passado, o cinema brasileiro acompanha o movimento de Caveirinha e sua derrota ante a decisiva fuga de Guigui dos holofotes que queriam celebrizá-la por instantes (Boca de Ouro); Marcelo, o angustiado de Saraceni, se vê trancafiado, mas emoldura um movimento no 
'Eagleton (1998, p.25) afirma que no pós-modernismo "questões mais abstratas de estado, categoria, modo de produção e justiça econômica mostraram-se por ora muito dificeis de solucionar, sempre podemos desviar nossa atenção para algo mais familiar e imediato, mais sensivel e particular". As narrativas da consolação sempre estiveram presentes na literatura e no cinema. A escolha por esse tipo de narrativa acompanha o contexto da época do filme: coercitivo, delicado e propício ao diagnóstico narrado pelos afetos e pela vida particular.

É um sintoma de um período em que optar pelo procedimento grifittiano era uma maneira de tentar "ganhar" o público e fazer a fotografia dos percalços da nação.

${ }^{2} \mathrm{~A}$ discussão sobre a história e os limites do melodrama no Brasil passa pela análise atenta de Ismail Xavier, com base, entre outros, no clássico estudo The Melodramatic Imagination de Peter Brooks. Nesse livro, Brooks (1985) aborda o gênero na literatura, especialmente Henry James e Balzac. Ver também Capuzo (1999) que, ao contrário, defende Griffith e o melodrama, quando afirma que "a importância de sua contribuição [Griffith] está na elaboração de estratégias que permitem ao cinema dar conta dessas estruturas narrativas". Recentes estudos sobre a telenovela brasileira, como o de Borelli \& Lopes (2002), procuram abordar o melodrama pelo viés da Teoria da Recepção. 0 estudo valoriza a atualização do melodrama feito no Brasil e aponta seus significados importantes (entre todas as classes sociais), a partir da visão do receptor. da ebuliçāo do Cinema Novo. O projeto agora éganhar o público de forma simpática e tentar concorrer com os filmes americanos. A fase das experiências e o diagnóstico da derrota foram estampados por Paulo Martins. Para o jornalista, restou a fuga ou a adesão. Babenco vai caminhar no sentido de tentár equilibrar o desterro e o apego ao regime. $\mathrm{O}$ vigor do cinema brasileiro, naquele momento, permite caminhar no sentido da verificação de uma particularidade, uma história pessoal e, por meio dela, procura fazer um diagnóstico do país ${ }^{1}$. Estratégia delicada, pois os diagnósticos do passado, feitos pelo do cinema, dedicaram uma abordagem corajosa tanto na forma como no conteúdo. $\mathrm{Na}$ ânsia pela aceitação imediata do público, o "policial-político" engendra uma trama em que os pressupostos estéticos da década anterior são jogados no baú de ossos.

O que importa, para Babenco, é trazer à tona uma verdade escondida na figura de Noquinha (Reginaldo Farias), o nome afetivo e íntimo de Lúcio Flávio. A oposição será entre a mentira pública e a verdade privada (Xavier, 1993). Lúcio Flávio, bandido, vai lutar contra as forças que o levam ao declínio eà morte. Sua vida íntima revela um ser amoroso, dono de uma sinceridade que causa empatia e o destaca como herói. O herói de Louzeiro e Babenco vai se debater todo o tempo contra o sistema e a sua engrenagem. Não é mais um diagnóstico da totalidade que está em jogo, e sim uma particularidade, ressonância do fracasso do projeto do país verificado nos filmes anteriores. A visada de Babenco é a de restituir criticamente o descalabro de um projeto abortado simbolicamente no foguete de Brasil Ano 2000. O foguete é o símbolo de um projeto que não se sustenta e o jornalista-fotógrafo é aquele que denuncia cinicamente, sem assumir os encargos políticos, o fracasso, a queda.

Lúcio Flávio, o filme, tenta esmiuçar o preço pago por um projeto nacional coercitivo, examinando as entranhas desse regime. Se Paulo Martins, em Terra em Transe, tenta "encontrar o povo em nome do qual se legitimaria a verdade, a justiça e a beleza" (Mainieri, 2002), Babenco faz do seu herói a encarnação da verdade do oprimido em outro viés. Paulo Martins enxerga a política como fórum para o estabelecimento da verdade. Lucio Flávio é a exaltação da "verdade privada", íntima, pessoal, contra um sistema podre, em que os pedaços do foguete são simbolizados pelas figuras lúgubres dos policiais corruptos chancelados pelos militares.

Babenco erige a possibilidade de um diagnóstico eficaz dos anos 70. Mas o cinema brasileiro, naquele momento, já flerta com o beneplácito do público, pois seu projeto não é mais o de alavancar a experiência com a forma e a conexão com a política. Há um intuito de reforçar uma ligação com temas que possam valorizar o sentimento nacional, sem partir para questionamentos mais complexos.

Babenco tenta fazer o diagnóstico de um período difícil e procura colocar os dispositivos paramilitares em visibilidade. Porém, faz a escolha e o estatuto fundador da linguagem em Griffith volta a vigorar com ênfase.

Uma moral privada vai se debater contra uma mentira pública, avalizada inclusive pela imprensa, para demonstrar as armadilhas a que estão sujeitos os indivíduos descartados por uma engrenagem truculenta. As intençōes revelam a batalha do indivíduo contra o sistema policial da época: cativa pela "sinceridade honesta" de Lúcio Flávio, avalia o Governo militar por mostrar a impunidade dos policiais e indica a valorização do "individual" diante do mundo externo, onde impera o vício, e não a virtude. Com o herói, Babenco vai construindo um novo diagnóstico do país e revelando, ao seu modo, um cardápio de intrigas que têm os seus problemas.

Seu filme esbarra nos limites do melodrama. Daí um diagnóstico que, ao privilegiar a forma de base griffitiana, interrompe o ciclo buliçoso e ousado da década anterior. Ao fazer a opçáo pelo acerto de contas com o regime, usando a "conspiração exterior" contra a virtude sincera do herói, abusando dos signos da vitimização ${ }^{2}$ e comunicado-se rapidamente com o público por meio da expiaçáo do bem na luta contra o mal, o malogro da empreitada se faz presente, pois irrompe na estrutura da narraçáo a atenuação do conflito, por uma pedagogia que náo tenta a mínima abordagem racional. 
O recorte da representação do jornalista é sintomático do encontro entre a abordagem atenuante e a objetividade que se instaura nas intervençóes do jornalista. Em Lúcio Flávio, o jornalismo impresso cede lugar ao jornalismo televisivo. Caveirinha tinha um nome e uma mínima identidade; Marcelo é protagonista e mesmo na sua "inércia perplexa" faz ouvir sua voz; o repórterfotográfico de Brasil Ano 2000 é um agente de informação, pois a manipula e emite opiniāo. Nos anos 70 , o jornalista começa seu processo de coadjuvante na progressiva mutação que leva o jornalismo a ser submetido aos ditames do marketing e das relaçóes públicas no processo de comunicação. O repórter de televisão aparece de forma objetiva. Sua performance é a de quem não tem autonomia e as intervençóes que faz permanecem no nível do jornalismo declaratório. Aparece sempre na companhia da polícia e se posta infantilmente num jogo de forças em que é elemento secundário (ver adiante comentário sobre a recepção no Brasil, contida nas teses sobre jornalismo, no livro Sobre a televisäo de Pierre Bourdieu).

Sua participação insípida garante a objetividade jornalística. No momento em que Lúcio Flávio é preso pela polícia, o repórter entrevista Janice (Ana Maria Magalhães), mulher do bandido, e faz a pergunta: "Você está consciente de estar junto com um criminoso?”. Por outro lado, ouve mecanicamente o delegado para saber como foi o assalto. É o exemplo tipico de um jornalista que sequer age com a perspicácia de Caveirinha. Seu movimento e fala são burocráticos. Em seguida às entrevistas, emite uma "opiniāo" rasa, clichê: "A população requer uma maior ação da polícia".

Seu comentário é o exemplo cristalino da objetividade que passa a dominar praticamente todo o jornalismo brasileiro. Não há um encaminhamento no sentido da checagem da notícia. Ele ouve de forma mecânica os "dois lados" e sequer refaz o círculo da reportagem, pois não há o menor grau de investigaçăo. Ele acredita na "verdade" da polícia, sem apurar os fatos. $\mathrm{O}$ assalto, na verdade, não foi realizado pelo bando de Lúcio Flávio. É o Esquadrão da Morte, junto com alguns grupos da polícia, os quais não precisam mais dos seus serviços, que passam a informaçāo falsa. Por fim, insiste com Janice que responde com o efeito melodramático: ela está ao lado dele porque o ama e por ser ele mais íntegro que muitos. Com um bebê nas mãos, no sentido de realçar a família e a intimidade pura do herói injustiçado, Janice corre do repórter e vai ao encontro do marido. Essa cena antevê o espetáculo da notícia, com a hegemonia do telejornalismo sobre o jornalismo impresso. A câmera posta-se dentro do carro e vemos Janice correndo com a criança na infrutífera tentativa de alcançar o olhar desesperançado do marido. Antes, ele tenta agredir o repórter, e outros cinegrafistas gravam a cena. Espetáculo armado, o repórter informa o que desconhece dos bastidores do crime organizado.

Guigui, em Boca de ouro, é utilizada e se utiliza de Caveirinha. Seu movimento indica algum grau de autonomia diante do que possa vir a ser notícia. Ela sabe da seduçáo do repórter com a linguagem e a imagem fotográfica. Janice não tem um Caveirinha que se arma de artimanhas da língua e da malícia para se contrapor; Guigui vai levando a notícia para o ponto que deseja. O repórter não perde o estímulo com a sinuosidade da história: entra num jogo, burla a intimidade do casal, propôe ser juiz de um atrito doméstico, invade o lar e tenta subtrair a notícia, o furo de reportagem. Vale tudo pela notícia. Mas há espaço ainda para a nuance do repórter e um pouco de autonomia. Caveirinha perde com a desistência de Guigui em fazer parte do espetáculo da notícia. É enganado, ludibriado e a cena de fracasso, em pleno centro do Rio de Janeiro, é memorável. Não ganhou o prêmio Esso e a psicologia, nova arma do jornalismo, não se mostrou eficaz. Porém, os dois Nelsons, mas principalmente o Rodrigues, jornalista de redaçāo impressa, dá alguma margem ao atrevimento e ousadia de Caveirinha.

Babenco representa um jornalista sem alma e ousadia. Trancafiado pelos

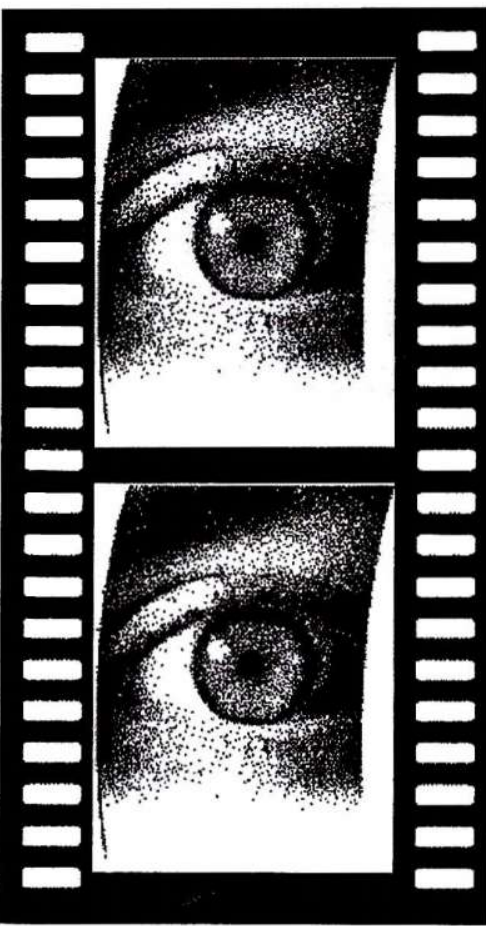


${ }^{3} \mathrm{O}$ uso do conceito de melodrama convida automaticamente a lembrança do cinema norteamericano. Mas o gênero sofreu atualizaçōes e renovaçōes tanto na Europa como no Brasil e até mesmo nos EUA. Na Europa, o exemplo clássico é Pedro Almodóvar com os filmes Atame, De salto alto, Tudo sobre a minha mãee Fale com Ela. São filmes em que o melodrama é revisto, ironizado e elevado a formas mais sofisticadas de narrativa. № Brasil, o exemploéArnaldo Jabor com suas adaptações de Nelson Rodrigues: $O$ casamento e Toda nudez será castigada Nesses filmes, o melodrama é intoxicado de "exageros", que levam personagens ao delirio. Mesmo nas telenovelas brasileiras, houve a tentativa de atualização do gênero, procedimento abortado no inicio dos anos noventa, tendo como marco simbólico a novela ODono do Mundo, de Gilberto Braga.

${ }^{4}$ Sobre a questão do envolvimento entre imprensa, e Estado ver Ideologia e técnica da notícia (Lage, 1979), O mundo dos jornalistas (Travancas, 1993) e Sobre ética $e$ imprensa (Bucci, 2000). rigores da censura e pela embrionária indústria de televisão que direciona a notícia para o espetáculo, resta um pálido entrevistador burocrático a apoiar o show melodramático de Janice. Resta-lhe a objetividade bisonha: fala em nome do povo que clama por mais segurança. Ao optar por essa representação, o cineasta esconde quase todos os procedimentos de bastidores efetuados pelas empresas de informação e pelo Estado, e os coloca na conta do jornalista. Faz um acordo com a Polícia Federal para nāo desnudar esse aparelho policial, sabendo, desde cedo, que essa corporação participou ativamente dos problemas com o Esquadrão da Morte. São acordos que o cineasta julga necessários, contudo, a fatura recai sobre o jornalista e uma corrupta polícia, da qual nāo se sabe se federal ou estadual. Ou seja, o manejo do filme, seguindo a cartilha griffitiana, é no sentido de camuflar responsabilidades, erguer um herói, reduto da verdade apesar de matar, roubar e compartilhar a corrupção do aparelho policial-, e evidenciar a "verdade íntima" contra uma "mentira pública". A responsabilidade final em ascender o herói ao papel de vítima recai sobre o jornalista de óculos e bigode (o jornalista de Lúcio Flávio não tem nome), repórter de televisão, e seus colegas que participam da coletiva.

$\mathrm{O}$ jornalismo afeito à objetividade contribui para esse tipo de papel a ser desempenhado pelo jornalismo. Assim como no melodrama ${ }^{3}$ de matriz americana, Lúcio Flávio cerca-se do jornalismo para legitimar uma ação da qual emerge a verdade do personagem. Sua verdade se nutre da natureza bondosa, corrompida pelo sistema, pelo qual tem rancor. O jornalista ressalta e reforça essa vitimização ao não escolher um pouco de subjetividade no trabalho com a notícia. Aparentemente, se posta contra o bandido do qual a sociedade quer se ver livre. Mas, na coletiva, as perguntas ingênuas, algumas superficialmente afoitas e outras completamente objetivas, fazem com que o tablado do mártir seja erguido. A uma pergunta sobre quanto já tinha roubado, ele responde "heroicamente" que "seria um pouco mais que os jornais te pagam para fazer perguntas imbecis". À outra indagação sobre quantas vezes fugiu da cadeia, responde para os jornalistas: "Vocês acreditam no que publicam os jornais?". O recurso da objetividade cria as condiçóes para o jornalismo escorar um herói e contribui para esconder outros poderes.

No final da década de setenta, a indústria da informaçāo já tinha se modernizado o suficiente, e o acolhimento da objetividade veio facilitar a uniāo de interesses entre as empresas e o governo militar. Financiada ${ }^{4}$ em grande parte pelo Estado, a imprensa dos anos 70 já não tem a mesma desenvoltura daquela do início e meados dos anos 60 . Edifica-se um mecanismo na linguagem jornalística para dar conta da "mentira pública" narrada pelos jornais e televisôes. É ela que fornece a certidão de confiabilidade entre o poder oficial e o poder da mídia. No plano narrativo, isso fica evidenciado nos momentos crucias de ação da polícia, quando a imprensa é sempre coadjuvante. Em Terra em Transe, de Glauber Rocha, o jornalista Paulo Martins vive o impasse do aval ao governo. Nele, o jornalismo assume sua total ambigüidade perante o poder. Ele hesita, critica, adere, descrê e fecha com o delírio:

Coloca-se a serviço do Partido quando este o pressiona, mas gosta muito da burguesia a serviço da qual ele está. No fundo ele despreza o povo. Ele acredita na massa como fenômeno espontâneo, mas acontece que a massa é complexa. A revolução não estoura quando ele a deseja e por isso ele assume posição quixotesca. No fim da tragédia, ele morre (Rocha, 1981).

Sua posição ambígua e quixotesca é sintonizada com uma identidade. Como o cineasta emprega o recurso da alegoria e despreza a narrativa linear, seu poder de intervençāo é mais elástico, para năo dizer autônomo. Com esse poder, o cinema de autor enaltece a figura do cineasta e abrelhe os caminhos para a invenção. Daí a questão da escolha e os seus resultados. Mesmo ambíguo, o jornalista de Terra em Transe aposta na febre da dúvida e se 
sufoca com as incertezas suscitadas. Há vida no delírio de Paulo Martins: seu medo e seu fascínio pelo poder, seu ódio e sua complacência com o povo ignorante e covarde, e sua "opiniāo comprada", que caracteriza um jornalista acuado pelos poderes.

O contexto político da época favorecia, em parte, as ousadias já não permitidas em Lúcio Flávio. A escolha do tratamento da narrativa, o enfoque da temática e a opção pela comunicação rápida com o público, apesar do contexto político desfavorável, demonstram a opção de um cineasta por um tipo de representação. Assume-se uma narrativa na qual as possibilidades de ousadia na forma e no conteúdo são limitadas, e as escolhas emolduram e corroboram também um tipo de pensamento e opinião. Daí não haver espaço para a ambigüidade de Paulo Martins, a ousadia mesmo que derrotada de Caveirinha e a dualidade de forma e conteúdo de $\mathrm{O}$ desafio.

A opção pela objetividade derrota os jornalistas em volta da mesa onde se posta a Polícia Federal e Lúcio Flávio. Babenco tem na mesa a Polícia Federal (Estado oficial), o bandido-herói (a vítima), os dois policiais corruptos (o Estado paralelo) e os jornalistas (o poder que constrói a "mentira pública"). A câmera passeia pelo rosto dos jornalistas e as perguntas reforçam a verdade que só Lúcio Flávio possui; quando ele aponta para os dois policiais, desmascarando e abrindo o jogo sujo do qual se beneficiou, os repórteres não emitem uma só palavra e a porta se fecha para se ouvir a última frase em plano fechado: "Bandido é bandido e policia é polícia”. Ou melhor: autêntico é autêntico e hipócrita é hipócrita, sacramentando a escolha do filme em atualizar o melodrama griffitiano do bem contra o mal. Lúcio salva o seu discurso e consegue a nossa simpatia. Confirmando a destinação consoladora do melodrama e seu apego à superfície dos fatos, só resta aos policiais a saída da sala, ou seja, a "saída de compromisso" de que nada vai acontecer, porque o que interessava no plano narrativo já foi feito: deixar o herói salvo moralmente. Resta ao jornalista dar o suporte de "verdade", tanto aos autênticos (Lúcio Flávio) quanto aos hipócritas (Polícia Federal e Civil), com a falsa neutralidade da objetividade jornalística.

\section{Abstract}

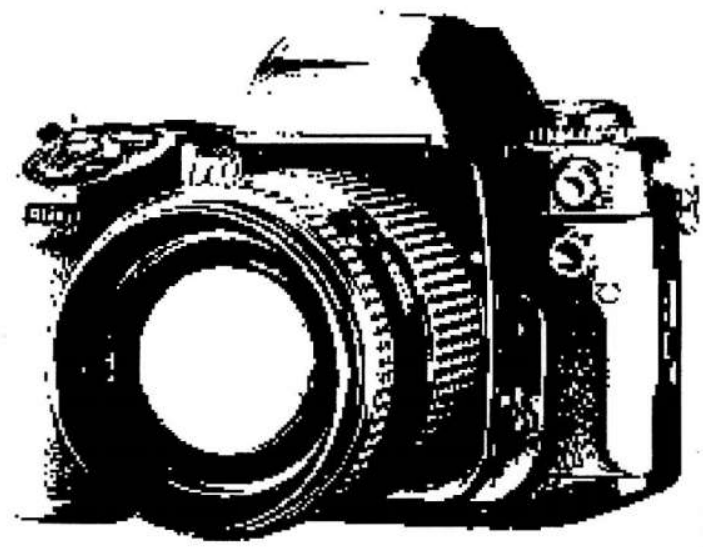

The portraiture of the journalist in brazilian movies of the 1960 s is different from that of newspaper movies of the same period. In the films Boca de Ouro(1962), O Desafio(1965) e Terra em transe(1967) which discard melodrama as a narrative technique, the journalist is neither a hero or a vilain. From the $1970 \mathrm{~s}$ on, this approach extinguishes and brazilian newspaper movies became more similar to the american model. Lucio Flávio, o passageiro da agonia is an exemple of a new way of portraying the journalist in the brazilian cinema.

Key words: Cinema and journalism, newspaper movies, journalist, brazilian movie.

\section{Bibliografias}

Bourdieu, Pierre. Sobre a televisão. Rio de Janeiro: Jorge Zahar, 1997.

Brooks, Peter. The Melodramatic Imagination, 1985

Bucci, Eugênio. Sobre ética e imprensa. São

Paulo: Companhia das Letras, 2000

Capuzzo, Heitor. Lágrimas de luz. Belo

Horizonte: Editora UFMG, 1999

Eagleton, Terry. As ilusōes do pósmodernismo. Rio de Janeiro: Jorge Zahar Editor, 1998.

Lage, Nilson. Ideologia e técnica da notícia. Petrópolis: Vozes, 1979

Rocha, Glauber. Revoluçāo do Cinema Novo. Rio de Janeiro: Embrafilme, 1981 Travancas, Isabel Siqueira. $O$ mundo dos jornalistas. São Paulo: Summus, 1993

Xavier, Ismail. A força e os limites da matriz melodramática. São Paulo: Revista USP, n.19, 1993 